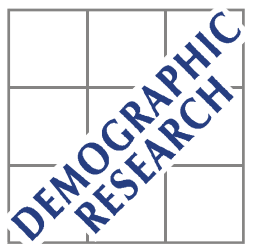

Demographic Research a free, expedited, online journal of peer-reviewed research and commentary in the population sciences published by the Max Planck Institute for Demographic Research Konrad-Zuse Str. 1, D-18057 Rostock · GERMANY www.demographic-research.org

DEMOGRAPHIC RESEARCH

VOLUME 11, ARTICLE 2, PAGES 43-56

PUBLISHED 13 AUGUST 2004

www.demographic-research.org/Volumes/Vol11/2/

DOI: 10.4054/DemRes.2004.11.2

Research Article

\title{
Under-Five Mortality in Nigeria: Perception and Attitudes of the Yorubas towards the Existence of "Abiku"
}

\section{Peter O. Ogunjuyigbe}

(C) 2004 Max-Planck-Gesellschaft. 


\section{Table of Contents}

1 Introduction $\quad 44$

2 Data and method $\quad 46$

$\begin{array}{lll}3 & \text { Sample characteristics } & 47\end{array}$

$4 \quad$ Belief in the existence of "Abiku"

$5 \quad$ Treatment of "Abiku" children $\quad 50$

6 Conclusion $\quad 52$

References $\quad 54$ 


\title{
Under-Five Mortality in Nigeria: Perception and Attitudes of the Yorubas towards the Existence of "Abiku"
}

\author{
Peter O. Ogunjuyigbe ${ }^{1}$
}

\begin{abstract}
The paper examines the perception and attitudes of the Yorubas about the existence of abiku (children from the spirit world) and the mode of treatment given to such children. The study elicited information from 1695 women of reproductive age in Ondo and Ekiti state of Southwest Nigeria. The study shows (i) that more than half of the respondents believe in the existence of abiku children; (ii) that abiku children can be identified from the evidence of past death, frequent indisposition, non-responsiveness of their illness to modern medical care as well as repeated death and verification from traditional healers; (iii) that causes of illness differ between abiku and non-abiku children; (iv) close to 71 percent of the respondents have faith in traditional methods of treatment for abiku children. The study, therefore, reiterate the need to integrate the people's beliefs, attitudes and behavioural practices into health promotion programmes.
\end{abstract}

${ }^{1}$ Department of Demography and Social Statistics Obafemi Awolowo University, Ile-Ife Email: pogunjuyigbe@yahoo.com 


\section{Introduction}

Infant and child mortality remain disturbingly high in developing countries despite the significant decline in most parts of the developed world. The state of the world's children indicated that about 12.9 million children die every year in developing world (UNICEF, 1987). Also, the Nigeria Demographic and Health Survey (NDHS), 1990 reported that 87 of 1000 infants born in Nigeria die before their first birthday while 115 of 1000 children die before reaching age five (FOS, 1992). The 1999 NDHS reported an infant mortality rate of 75 deaths per 1000 live births and under five mortality rate of 140 deaths per 1,000 live births for the 1995 to 1999 period. Also, review of trends in under five mortality rates between 1960 and 1998 by UNCEF (2000), based on an estimate of 187 deaths per 1,000 for 1998 indicates a 10 percent reduction in Nigeria. According to the Nigeria Demographic and Health Survey (NDHS), 1999, infant mortality and under five mortality rates for the ten years period preceding the survey for the south western part of Nigeria, the focus of this study, are 70 per 1,000 and 102 per 1,000 live birth respectively (NPC, 2000). For five years immediately preceding the 1999-2003 survey, the infant mortality rate was 100 deaths per 1,000 live births, while the overall under-five mortality rate was 201 deaths per 1,000 live births (NPC, 2004). The level of improvement in infant and child mortality in Nigeria as a whole is significantly lower than the average of 34 percent for the sub-Saharan Africa.

Common causes of child mortality and morbidity include diarrhea, acute respiratory infections, measles, and malaria. Studies have shown that many children in Nigeria die mainly from malaria, diarrhea, neonatal tetanus, tuberculosis, whooping cough and bronchopneumonia (Tomkins, 1981; Ayeni, 1980; Animashaun; 1977; Morley, 1973; Baxter-Grillo and Leshi, 1964; Ogunlesi, 1961). Mosley and Chen (1981) also viewed morbidity and mortality of the child as being influenced by underlying factors of both biological and socio-economic, operating through proximate determinants. Jinadu et al. (1991), in a study, found dirty feeding bottles and utensils, inadequate disposal of household refuse and poor storage of drinking water to be significantly related to the high incidence of diarrhea. Studies have also shown maternal education to be a significant factor influencing child survival (Caldwell, 1979; Orubuloye and Caldwell, 1975; Meegama, 1980; Tawiah, 1979; Adewuyi and Feyisetan, 1988).

Knowledge of measles and diarrhea is quite pertinent in an understanding of the role of cultural beliefs in health seeking among the Yoruba. In the traditional Yoruba setting, measles attack is usually attributed to a variety of causes which have no link with the concept of virus (Odebiyi and Ekong, 1982). Measles attack is traditionally considered as a punishment for breaking family taboos or as an evil deed from witches or enemies. The belief that the measles attack is caused by enemies is common among 
polygynous family where co-wives are natural suspects. While measles is perceived as deadly disease among the Yorubas, diarrhea is perceived merely as a means of getting rid of body impurities or as a sign of 'teething', 'crawling', or 'stretching'. Also some mothers believe that diarrhea is caused by consumption of sweet things (Jinadu et al., 1991). Mothers with this view will not likely introduce oral rehydration solution to their children since it contains sugar and salt.

Despite the fact that the major childhood diseases have been identified and modern technology to combat them developed, yet, children from African countries (Nigeria inclusive) die in large number from the attacks of these diseases. The adduced reason is deeply rooted in people's beliefs and attitudes concerning childcare and behavioural practices into health strategies (Parry, 1984; Uboma-Jaswa, 1988; Feyisetan, 1988; 1990; Feyisetan and Adeokun, 1989). The Nigerian Health Policy recognizes the need to reduce the current high childhood morbidity and mortality rates, but people's belief and behavioural practices have not been adequately integrated into the health intervention programmes.

The non-disease specific beliefs among the Yorubas, is the existence of "Abiku" (children from the spirit world who can die at will). The Yorubas belief that some children are from the spirit world and they will eventually return to the spirit world after a short period of time on earth unless certain rituals are performed. Abikus are described as spirit children whose mercurial treatment, even rejection, of their parents (mothers especially) leave the mothers in most pitiable state (Soyinka, 1981; Okri, 1995 and Ogunyemi, 1996). Abiku children inflict a lot of pain and agony on their mothers. The pain suffered by the mothers of abiku and the efforts made by abiku mothers to placate their obviously mischievous, pain-causing offspring were succinctly displayed in Soyinka's (1981), Achebe's (1986) and Okri's (1993) works. The Igbo of Southeast Nigeria call the living icon 'Ogbaje' (Achebe, 1958 and Achebe, 1986). The ogbanje child also emerges as a frequent traveler between the world of the living and the place of the friendly dead (Achebe, 1958, Quayson, 1997). The notion of abiku or ogbanje is a common phenomenon in West African countries.

Recognising the implication of this belief for child health and its survival and upon the recognition of the fact that children under-five constitute an important segment of the Nigerian population, this paper, therefore, attempts to examine the perception and attitudes of the Yorubas about the phenomenon called "Abiku". The existence and the mode of treatment of "Abiku" as well as the "non-abiku" children are discussed in the paper. 


\section{Data and method}

The objectives of the study were to identify people's perceptions of the etiology of certain childhood diseases and determine the impact of such perception of healthseeking behaviour, determine mothers' knowledge and use of health services; identify maternal and childhood feeding practices; and determine the impact of health-seeking behaviour and other child care practices on child morbidity and mortality in Ekiti and Ondo states of Southwest Nigeria. In order to achieve these objectives, a survey on the people's perception, etiology and cultural beliefs in Ekiti and Ondo states was conducted between 1999 and 2000. The study elicited information from 1695 eligible women of reproductive age (15-49 years) from the selected rural and urban areas in five selected Local Government areas of Ekiti and Ondo states. The data were collected from Akoko North, Akure, Ijero, Ikale and Isokan Local Government Areas (three from Ondo and two from Ekiti). A multistage, stratified random sampling design was used to select respondents from the towns. In the rural areas, selection of respondents was by simple random sampling technique. However, the random selection was made in such a way that all the different parts of the locations were represented. From the data collected, indirect infant morbidity and child mortality estimates were obtained.

Brass is one of the proponents of indirect method of mortality estimation. He based his mortality estimate on retrospective data given by women of reproductive age on the number of children ever born and their status (either dead or living). Other contributors in this line include Sullivan (1972), Trussel (1975), and Preston and Palloni (1978). However, indirect infant and child mortality estimates result from poor, inadequate and incomplete data especially in developing countries. Most deaths outside hospital premises were not recorded and that many people do not record infant deaths because they regard such occurrence as misfortunes, and when recorded, the age at death were either understated or overstated.

The method adopted in this study is the Lotus Program for the calculation of mortality by Samoza (1980). The variables examined include age, religion, education, type of place of residence, perception of illness, health seeking behaviour and the respondents occupation as well as fertility-related variables such as children ever born, own children five years and under, age at marriage etc. Data analysis was carried out using both univariate and bivariate approaches. The univariate analysis deals with the frequency distributions that show how varied the respondents are on socioeconomic, child care and health seeking behaviour variables. At the bivariate level, the simultaneous analysis of two variables was carried out. The relationship either between socioeconomic variables and child health seeking behaviour as well as between child health and health seeking variables were examined. For the bivariate analysis, interval 
measured variables were changed through recoding into ordinal variables with few categories.

\section{Sample characteristics}

The socioeconomic characteristics of the respondents are presented in Table 1 . The table shows that majority of the respondents fell within age range 30-39 (42.1 percent). Nearly equal number of respondents were interviewed from the rural and the urban locations (50.5 percent and 49.5 percent in urban and rural areas respectively). More than 90 percent of the women had received formal education. The highest being secondary or higher levels with 40.5 percent. Majority of the respondents (90.4 percent) professed to be Christians. The Muslims constitute only 7.4 percent of the total population, while those who are traditionalists represent only 1.2 percent of the whole respondents. About 86 percent of the respondents claimed to own one or two children under five years of age, while only 1.2 percent claimed to have 4 or more. Majority of the respondents engage in either sales or services ( 58.8 percent), while close to 33 percent are also found in agriculture.

\section{Belief in the existence of "Abiku"}

Respondents were asked to indicate whether or not they belief in the phenomenon called "Abiku". The distribution of mothers according to responses to the questions on "abiku" is presented in Table 2.

Panel 1 of the table indicates the persistence of this belief among the Yorubas. About 57 percent of mothers believe that there are abiku children; 30.1 percent do not share this belief and 12.9 percent are unsure of their beliefs. When the women were asked if they have ever had abiku children, only 15.4 percent of the mothers who believe in its existence answered in the affirmative (Panel 2). This finding is not surprising since many mothers, especially the educated ones, may not likely admit that they already have children they suspected to be abiku and none of their infants had died. Of the mothers who claimed to have had abiku children, 83.2 percent reported that the "abiku" children have died (Panel 3). Asking mothers to state "how an "abiku" child can be identified', panel 4 of Table 2 indicates such responses as: "evidence of

deformity from past death (such as being too dark in completion or having incomplete or deformed parts of body as the outcome of wounds inflicted on the body of previous child that died by the offended mother)." (27.4 percent); "frequent indisposition" (11.6 percent); "non-responsiveness of their illness to modern medical care" (17.9 percent); 
Table 1: $\quad$ Background characteristics of respondents (percentage distribution)

\begin{tabular}{|c|c|c|}
\hline Characteristics & Number & Percentage \\
\hline \multicolumn{3}{|l|}{ Age } \\
\hline $15-29$ & 673 & 39.7 \\
\hline $30-39$ & 714 & 42.1 \\
\hline $40+$ & 307 & 18.2 \\
\hline \multicolumn{3}{|l|}{ Residency } \\
\hline Urban & 856 & 50.5 \\
\hline Rural & 839 & 49.5 \\
\hline \multicolumn{3}{|l|}{ Education } \\
\hline None & 485 & 28.6 \\
\hline Primary & 523 & 30.9 \\
\hline Secondary \& higher & 687 & 40.5 \\
\hline \multicolumn{3}{|l|}{ Religion } \\
\hline Catholic & 266 & 15.7 \\
\hline Protestant & 863 & 50.9 \\
\hline Other Christians & 403 & 23.8 \\
\hline Islam & 125 & 7.4 \\
\hline Traditional & 21 & 1.2 \\
\hline Others & 17 & 1.0 \\
\hline \multicolumn{3}{|c|}{ Own Children 5 Years and Under } \\
\hline 1 & 647 & 38.2 \\
\hline 2 & 806 & 47.5 \\
\hline 3 & 222 & 13.1 \\
\hline 4 and above & 20 & 1.2 \\
\hline \multicolumn{3}{|l|}{ Current Employment } \\
\hline White Collar & 80 & 4.7 \\
\hline Sales/Service & 997 & 58.8 \\
\hline Agriculture & 552 & 32.6 \\
\hline Others & 66 & 3.9 \\
\hline No response & 297 & 17.5 \\
\hline Total & 1695 & 100.0 \\
\hline
\end{tabular}

and "repeated death and verification from traditional healers (39 percent). Information was also sought on (i) whether a suspected abiku child should be subjected to the same treatment as a non-abiku child and (ii) where treatment should be sought for a suspected abiku child when he/she is sick. Panel 5 of Table 2 shows that 61.7 percent of the respondents shared the believe that a suspected abiku child should not be treated like an ordinary child when he/she is sick. About 3 percent are not sure of the type of treatment to recommend to a suspected $a b i k u$ child. When asked 'where a suspected abiku should 
be treated', about 70 percent of the respondents mentioned traditional or spiritual healer's home (panel 6). This finding reflects the belief that illnesses of abiku are not caused by natural but by supernatural forces. Thus, such illnesses are believed to be incurable by 'mere administration of drugs or injections in the hospitals'.

Table 2: Percentage distribution of mothers by responses to questions on "Abiku"

\begin{tabular}{|c|c|}
\hline \multicolumn{2}{|c|}{1 Belief in the existence of "Abiku"? } \\
\hline Yes & $56.9(965)$ \\
\hline \multicolumn{2}{|l|}{ 2. Ever had "Abiku" child? } \\
\hline Yes & $15.4(149)$ \\
\hline No & $84.6(816)$ \\
\hline \multicolumn{2}{|l|}{ 3. Is "Abiku” child alive? } \\
\hline Yes & $16.8(25)$ \\
\hline No & $83.2(124)$ \\
\hline \multicolumn{2}{|l|}{ 4. Identification of "Abiku" } \\
\hline III too often & $11.6(112)$ \\
\hline Deformation from birth & $27.4(264)$ \\
\hline Illness non response to medicine & 17.9 (173) \\
\hline Other & $39.0(376)$ \\
\hline No response & $4.1(40)$ \\
\hline \multicolumn{2}{|c|}{ 5. "Abiku" child treated like others? } \\
\hline Yes & $35.3(341)$ \\
\hline No & $61.7(595)$ \\
\hline Don’t know & $3.0(29)$ \\
\hline \multicolumn{2}{|l|}{ 6. Place of treatment of "Abiku" } \\
\hline Hospital/Health Centre & $29.4(284)$ \\
\hline Traditional healer & $59.8(577)$ \\
\hline Church/Mosque & $9.2(89)$ \\
\hline Others & $1.6(15)$ \\
\hline \multicolumn{2}{|c|}{ 7. Place of treatment of "Abiku" that died } \\
\hline Hospital/Health Centre & $21.4(207)$ \\
\hline Traditional healer & $47.3(456)$ \\
\hline Church/Mosque & $14.4(139)$ \\
\hline Both traditional and orthodox & $27.9(163)$ \\
\hline
\end{tabular}

The percentages of mothers of different socio-economic backgrounds who claimed to have believe in the existence of abiku children are presented in Table 3. The table shows that older mothers are more likely than younger ones to hold the believe that abiku children exist. Education is negatively correlated with mothers' believe in the existence of abiku children. The table shows that higher proportion of Muslims hold this believe, however, significant proportion of Christians also believe in the existence 
of abiku. This is an indication that religion has not influenced or change the perception of the Yorubas concerning certain norms. Also, higher percentages of mothers in urban areas believe in the existence of abiku indicating that urban residency has not erase completely the perception of these women about certain socio-cultural norms. It should, however, be noted that significant proportion of people residing in urban areas in Nigeria are migrants from rural areas and modernization and westernization have not seriously influenced their cultural perspectives.

Table 3: $\quad$ Percentage distribution of mothers by believe in the existence of abiku and according to background characteristics

\begin{tabular}{lcc}
\hline Background & Number & Believe in the existence of abiku? \\
\hline Current age & 673 & 52.9 \\
$15-29$ & 714 & 51.5 \\
$30-39$ & 307 & 78.5 \\
$40+$ & & \\
Education & 485 & 62.9 \\
None & 523 & 68.3 \\
Primary & 687 & 44.1 \\
Secondary and higher & & \\
Religion & 266 & 47.0 \\
Catholic & 863 & 53.8 \\
Protestant & 403 & 69.7 \\
Other Christians & 125 & 76.0 \\
Islam & 39 & 69.2 \\
Others & & \\
Place of residence & 856 & 60.1 \\
Urban & 839 & 53.9 \\
Rural & & \\
Residence before age 12 & 636 & 59.7 \\
Village & 488 & 59.2 \\
Town & 491 & 60.3 \\
City & & \\
\hline
\end{tabular}

\section{Treatment of "Abiku” children}

According to traditional belief among the Yorubas, there are two categories of children namely abiku and non-abiku. Since causes of illness are believed to differ between the two groups, we asked mothers to 'state whether the two groups of children should be treated the same way when they are sick'. As indicated above, only 35.3 percent of 
mothers believe that an abiku child should be treated like any other child when he/she is sick. The percentage distribution of mothers who believe in similar treatment for both abiku and non-abiku children is presented in Table 4 according to their background characteristics. It is discernable from the table that (i) a clear pattern of association does not emerge between age of mother and the believe in similar treatment for abiku and non-abiku children (ii) education is positively correlated with the belief in similar treatment for the two groups of children (iii) the fact that less than half of women with secondary (or higher) education hold this belief is, however, a source of concern (iii) Catholic and Protestant Christian mothers are least likely to believe in similar treatment for the two groups of children (iv) rural dwellers are more likely to proffer similar treatment for the two groups of children. This pattern of differential by place of residence is unexpected because mothers in the urban areas, who are not only more exposed to Western ideas but also have higher concentration of modern health facilities, are expected to have more rational attitude than the rural dwellers. Finally, mothers who reside in the city before age 12 are most likely to proffer similar treatment for $a b i k u$ and non-abiku children.

As indicated above, close to 71 percent of the mothers suggested traditional health facilities as places to treat abiku children. Such facilities mentioned by these mothers include: traditional healer's home (59.8 percent), Church/Mosque (9.2 percent) and other traditional health facilities (1.6 percent). The percentage distribution of mothers who suggested these places by background characteristics is presented in Table 4 below. The table shows that: (i) the probability of suggesting a non-modern health facility does not vary among mothers who are under 40 years (ii) mothers with secondary or higher education are less likely to suggest traditional health facilities than mothers with primary or no education (iii) the probability of suggesting traditional health facilities does not vary much among different groups of Christian mothers (iv) urban residence is positively associated with the probability of suggesting a traditional health facility; and (v) mothers who reside in the city before age 12 are least likely to suggest traditional health facilities.

As mentioned above, majority of the mothers believed that spiritual healing should be sought for an abiku child, though some of them still combined traditional healing with orthodox healing. They believed in the efficacy of traditional healing methods, thus corroborating earlier findings by Okri, (1995), Morrison (1988), Quayson (1997) and Achebe (1958) concerning the treatment of abiku child. Panel 7 of Table 4 shows that majority of abiku children that died were treated in traditional healer's home (47.3 percent). The trust mothers in the area placed in faith-healing home was brought out in the study as 21.4 percent of the mothers still relied solely on churches or mosque for the treatment of dead children. Significant proportion of the mothers (27.9 percent) claimed 
to have used the combination of both orthodox and traditional healing methods in the treatment of dead abiku children.

Table 4: $\quad$ Percentage distribution of mothers who believe in the existence of abiku by type of treatment and according to background characteristics

\begin{tabular}{lccc}
\hline Background & Number & $\begin{array}{c}\text { Treat "Abiku" } \\
\text { children like } \\
\text { others }\end{array}$ & $\begin{array}{c}\text { Belief in non-biomedical } \\
\text { treatment for "Abiku" }\end{array}$ \\
\hline Current age & 356 & 37.3 & 68.1 \\
$15-29$ & 368 & 39.1 & 69.4 \\
$30-39$ & 241 & 32.3 & 75.1 \\
$40+$ & & & \\
Education & 305 & 32.3 & 72.4 \\
None & 357 & 34.6 & 74.6 \\
Primary & 303 & 41.1 & 65.2 \\
Secondary and higher & & & 76.1 \\
Religion & 125 & 27.6 & 70.2 \\
Catholic & 464 & 40.1 & 71.8 \\
Protestant & 281 & 28.6 & 64.5 \\
Other Christians & 95 & 48.1 & 68.3 \\
Islam & 27 & 36.4 & \\
Others & & & 74.0 \\
Place of residence & 514 & 32.6 & 67.2 \\
Urban & 451 & 39.7 & 74.6 \\
Rural & & & 70.4 \\
Residence before age 12 & 380 & 32.3 & 67.3 \\
Village & 289 & 34.1 & \\
Town & 296 & 41.5 & \\
City & & & \\
\hline & & & \\
\hline
\end{tabular}

\section{Conclusion}

We found out from the study that quite a lot of people do not have clear perception of illness and treatment while some attached the death of under-five children to abiku spirit. This has serious implication on under-five morbidity and mortality in Nigeria.

The ultimate goal of governments all over the world is to postpone the inevitable 'life ends' by reducing mortality to low levels and ensure the good health of all citizens. But in spite of a general decline in infant and child mortality in developing world, the rates are still high by world standard. The persistently high infant and child mortality 
level in Nigeria continues to be disturbing to both planners and policy makers. Despite the fact that the Nigerian Health Policy recognizes the need to reduce the current high childhood mortality, the people's belief and behavioural practices have not been adequately integrated into health intervention programmes. It is disturbing to find out that people are still holding on to their wrong perceptions and attitude towards the etiology of certain childhood diseases and deaths despite the positive effect that modernization and education are having on people's behaviour. As Morrison (1988) noted, a mother who sees her child gradually wasting away without apparent cause, concludes that an abiku has entered it, or, as the natives frequently express it, that she has given birth to an abiku, and that it is being starved because the abiku is stealing all its nourishment. Many people have not realized that infant morbidity and child mortality result from the combined effects of nutritional deficiencies, infections, parasitic and respiratory diseases. Mothers do not have clear perception of illness and treatment while some attached the death of under five to 'abiku' spirit. Therefore, there is need to integrate the people's beliefs, attitudes and behavioural practices into health promotion programmes to achieve a maximum reduction in child and infant morbidity and mortality. Unless this is done, there might not be too much progress as regards curtailment of infant and childhood morbidity and mortality in Nigeria. 


\section{References}

Achebe, Chinua (1958): Things Fall Apart, London: Heineman.

Achebe, Chinwe (1986): The World of the Ogbanje. Enugu, Nigeria: Fourth Dimension.

Adewuyi, A.A. and B.J. Feyisetan (1988): "Correlates of Infant Mortality: Empirical evidence from Ile-Ife, Nigeria”. Manuscript Report 191e IDRC, Canada.

Animashaun A. (1977): "Measles and blindness in Nigerian children" Nigeria Journal of Pediatrics 4(1): 10-13.

Ayeni, O. and S.O. Oduntan (1980): "Infant mortality rates and trends in Nigerian rural populations" Journal of Tropical Pediatrics and Environmental Child Health, 26(1): 7-10.

Baxter-Grillo, D.L. and F.E.A. Leshi, (1964): "Factors influencing the occurrence of neonatal tetanus in Ibadan" West African Medical Journal, v.13.

Caldwell, J.C. (1979): "Education as a factor in mortality decline: An examination of Nigerian data" Population Studies 33(3): 395-414.

Feyisetan, B.J. (1988): Issues in an examination of the relationship between maternal education and child mortality" IDRC: Proceedings of a workshop held in Accra on Research Issues in Child Health and Child Care.

Feyisetan, B.J. (1990): "The need to investigate disease-specific and other healthrelated cultural beliefs in child mortality studies" Proceedings of the International Seminar on Morbidity, mortality and social policy: A focus on the young and the elderly, held in Bello Horizone, Brazil, December 13-15.

Feyisetan, B.J. and L.A. Adeokun (1992): "Impact of child care and disease treatment on infant mortality" In E. Van de Walle, G. Pison and M. Sala-Diakanda (eds): Research Issues in Child Health and Child Care.

Federal Office of Statistics (FOS) (1992): Nigeria Demographic and Health Survey, 1990 Lagos.

Jinadu, M.K.; Olusi, S.O.; Agun, J.I. and A.K. Fabiyi (1991): "Childhood diarrhea in rural Nigeria: Studies on prevalence, mortality and socio-environmental factors" Journal of Diarrhea Diseases Research 9(4): 323-7.

Meegama, S.A. (1980): Socio-economic determinants of infant and child mortality in Sri Lanka: An analysis of post war experience, 151 WFS Scientific Reports No.8. 
Morley, D. (1973): Pediatric Priorities in the developing world, London: Butterworths. Morrison, Toni (1988): Beloved. Thorndike, ME: Thorndike Press.

Mosley, W.H. and I.C. Chen (1984): "An analytical framework for the study of child survival in developing countries" Population and Development Review, A supplement to Vol.10.

National Population Commission (2000): Nigeria Demographic and Health Survey, 1999. National Population Commission, Abuja, and Demographic and Health Surveys, IRD/Macro International, Inc.

National Population Commission (NPC) (Nigeria) and ORC Macro (2004) Demographic and Health Survey, 2003, Calverton, Maryland: National Population Commission and ORC Macro.

Odebiyi, A.I. and S.C Ekong (1982): "Mother's concept of measles and attitudes towards the measles vaccine in Ile-Ife, Nigeria". Journal of Epidemiology and Community Health 36(3): 209-213.

Ogunlesi, T.O. (1961): "Respiratory infections in the preschool child: A review of 435 cases admitted to Adeoyo Hospital, Ibadan" West African Journal, 10:231.

Ogunyemi, Chikwenye Okonjo (1996): African Wo/Man Palava: The Nigerian Novel by Women, University of Chicago Press.

Okri, Ben (1993): The Famished Road. New York: Anchor.

Okri, Ben (1995): "Spirit-child: Abiku Migration and Post-modernity", Research in Africa Literature 26(1): 20-29.

Orubuloye, I.O and J.C. Caldwell (1975): "The impact of Public Health services on mortality: A study of mortality differentials in a rural area of Nigeria" Population Studies, 29(20: 259-272.

Parry, E.H.O. (1984): "People and Health: The Influence of Culture" World Health Forum, Vol.5 pp.49-52.

Preston, S.H. and Palloni, A. (1978): "Fine tuning Brass-Type mortality estimation with data on age on surviving children" UN Population Bulletin, Vol.10, pp.72-91.

Quayson, A. (1997): Strategic Transformations in Nigeria Writing: Orality and History in the Work of Rev. Samuel Johnson, Amos Tutuola, Wole Soyinka and Ben Okri. Bloomington: Indiana University Press 
Somoza, J.L. (1980): "Illustrative Analysis: Infant and Child Mortality in Columbia" World Fertility Survey Scientific Reports, No. 10, May.

Soyinka, Wole (1989): Abiku. Senanu and Vincent.

Soyinka, Wole (1989): Ake: The Years of Childhood. New York: Vintage International.

Sullivan, J.M. (1972): "Models for the estimation of the probability of dying between birth and exact ages of childhood" Population Studies Vvol.26, No.1.

Tawiah, E.O. (1979): "Some demographic and social differentials in infant and early childhood mortality in Ghana" Population Dynamic: Fertility and Mortality in Africa, United Nations Economic Commission for Africa, Monrovia, Liberia, 26 November - 1 December.

Trussel, J. (1975): “A re-examination of the multiplying factors for Brass Technique for determining childhood survivorship rates" Population Studies, Vol.3, No.1.

Uboma-Jaswa, S.R. (1988): "Culture and Health: Lessons from data collection on child health in Ghana" IDRC: Proceedings of a workshop held in Accra on Research Issues in Child Health and Child Care, 100-101.

UNICEF (1987): The State of the World's children, Oxford University Press.

UNICEF (2000): The State of World's Children, UNICEF, New York. 